\title{
UGT1A4 wt Allele
}

National Cancer Institute

\section{Source}

National Cancer Institute. UGT 1A4 wt Allele. NCI Thesaurus. Code C113633.

Human UGT 1A4 wild-type allele is located in the vicinity of $2 q 37$ and is approximately 55 kb in length. This allele, which encodes UDP-glucuronosyltransferase 1-4 protein, plays a role in the catabolism of xenobiotics. Mutation of the gene is associated with Gilbert syndrome and Crigler-Najjar syndrome types 1 and 2. 